\title{
Evaluation the Lesson Plan of English Language Learning in Junior High School, Seraphine Bakti Utama West Jakarta
}

\author{
Hendrico Dolok Mauliate ${ }^{1}$, Aceng Rahmat ${ }^{2}$, Siti Wachidah ${ }^{3}$ \\ ${ }^{1}$ Postgraduate Student, Jakarta State University, Indonesia \\ ${ }^{2}$ Lecturers, Jakarta State University, Indonesia \\ ${ }^{3}$ Lecturers, Jakarta State University, Indonesia
}

\begin{abstract}
The study aims to evaluation the lesson plan of english language learning. This research was conducted at the Junior High School, Seraphine Bakti Utama West Jakarta. The research methodology used is evaluative through the flow of the gap model (discrepancy evaluation model). Data collection through interviews, document tracing, and observation. Key informant is the principal, teacher, and student. The results showed that: (1). The use of the lesson plan drafting principles occurs a negative (-) gap that resides in the quadrant (-2) because it earns a value of $40 \%$, particularly on the full aspects of the basic competency of spiritual attitudes, attitudes Knowledge and skills, centered on students, context, kinship, feedback and alignment. (2). The implementation of lesson plan preparation of the (+) gap occurred at the Quadrant (2) because it gained a value of $60 \%$, especially in the aspect of syllabus assessment, and the development of learning assessments. (3). In the implementation of lesson plan there is a negative positive (-) gap that resides in the quadrant (-2) because it has a value of $40 \%$, especially in the introduction of activities, core activities and closures. In conclusion, the preparation of lesson plan should refer to Permendikbud No. 103 year 2014 about learning in primary education and secondary education.
\end{abstract}

\section{Keywords: Evaluation, Lesson Plan, English Language}

\section{Background}

Learning a language is how students to be able to communicate using language that is being either orally or in writing. English language learning success is measured on the ability to communicate with the students themselves. This then implies that the indicators of the success of students learning English in school is not in line with the basic principles of language learning which states that language learners, especially students can communicate in English both orally and in writing that the fact that students are still considered not able to communicate using a foreign language after graduation.

Related to this is the teacher in this case English teacher in Seraphine Bakti Utama West Jakarta expecting success in his duties as a language teacher to make students succeed in learning English. Students can use language to communicate well in both written and spoken. To achieve success in learning and teaching languages to students, a teacher must have the skills and qualifications of teaching, always followed that training, working with a colleague or mentor, master teaching materials, planning and learning objectives and to evaluate learning.

Circumstances on the ground that the students who take courses in English, foreign language communication skills if they were considered better than the students who are just learning to rely on learning in school. This is several times the author encountered when monitoring students who are taught by students who joined PPL in Seraphine Bakti Utama West Jakarta. Most of the students who are capable and active in the class are those who have or are to follow additional courses beyond the classroom and have a strong motivation to master the English language. The student's English ability is considered better than students who do not attend courses. 
Based on the description and the issues raised above authors reasoned to conduct research on for evaluation the lesson plan of english language learning. This research was conducted at the Junior High School, Seraphine Bakti Utama West Jakarta.

\section{Literature Review}

\section{Evaluation}

Activities to evaluate and measure the success of a program known as program evaluation. There are several definitions of evaluation proposed by experts. The definition has been known quite extensive, including the definition put forward by Neumann, Robson and Sloan (2017) that evaluation in terms of an activity being systematic, planned and purposeful, involving the collection of data on questions and issues relating to the organisation and its change programme. Evaluation is an activity that is systematic, planned and achieving goals, involves the collection of data relating to the organization and program.

According to Molly, et. al, (2017) that evaluation often occurs for the purpose of comparing success across programs competing for similar resources. The evaluation was conducted to assess the success of a program that has been implemented. In human life, the evaluation is not new because it is always accompany one's life.

Next Cimmings and Worley (2015) explains that evaluation is concerned with Providing feedback to practitioners and organization members about the progress and impact of interventions. The following evaluation, the evaluation concerned with providing feedback to practitioners and members of the organization on the progress and impact of interventions.

\section{Evaluation Model DEM}

There are various models of evaluation research presented by experts on the evaluation study. Grounded to the views expressed by Royse David, et. al (2010) that the program evaluation activities involve the benchmarking process, and can not be regarded as a form of evaluation in the absence of a form of benchmarking while the base. This is in line with Provus (1969), which revealed that there is no evaluation activities without the information gap.

Selection of evaluation models to be used in research activities is determined based on the focus, goals and evaluation questions were developed. Based on the formulation of the problem (evaluation questions) that have been formulated above, evaluation model used in this study is the gap or Discrepancy Evaluation Model Evaluation Model (DEM). This model is suitable to examine the effectiveness of programs to explore gaps in the view of program implementation in the field.

Model evaluation gap is the result of an attempt to apply the theory of evaluation and management to evaluate the program in an urban public school system. Provus (1969) This model was developed by Malcolm M. Provus based research in the public schools in the city of Pittsburgh Pennsylvania Office of Education in collaboration with the Department of Health, Education and Welfare of the United States.

The principle of the model evaluation is a process of comparing the gap between the display program in the field (performance) standards (standard), while the results of the benchmarking shows the information gap that can be used as a basis for making a decision about the value or usefulness of the object being evaluated. (Madaus, Michael Scriven and Daniel Stufflebeam, 1985).

A gap evaluation model aimed to obtain information gaps with a view to determine the effectiveness of programs in the field to see which is useful for decision making.

a. Unit I: Program Design

The design of the program is making a decision on the draft program description. In other words, the unit design of the program is the formulation of program evaluation criteria that will be used as a standard of evaluation.

Interest in the program design unit of this study is to analyze the application of the principles of the preparation of the lesson plan learning English in Junior Seraphine Bakti Utama, West Jakarta.

b. Unit II: Program Operation

In the evaluation unit operation of the program, the standards used to compare is obtained from the program design program design unit. Objective evaluation of the operation of the program in this study 
is to analyze the application of the preparation of the implementation of the measures of learning English in Junior Seraphine Bakti Utama in West Jakarta.

c. Unit III: Terminal Program Product

Evaluation of the final result of determining whether the program is the final goal is reached. Evaluation of program outcomes aims to create a follow-up study by the end of goal attainment overall program evaluation.

In a study conducted using only 3 units are units of program design, program operation unit, unit product program. This is done because the researchers did not assess the overall but just focus on the lesson plan.

\section{Lesson Plan}

According to Permendikbud No. 103 of 2014 the lesson plan, hereinafter referred to RPP is developed lesson plans refer to the syllabus. Lesson plan is derived from the syllabus to guide student learning activities in an effort to reach basic competence. Every teacher in the educational unit is obliged to draw up lesson plans complete and systematic so that learning takes place in an interactive, inspiring, fun, challenging, motivating students to actively participate and provide enough space for innovation, creativity, and independence in accordance with their talents, interests, and development physical and psychological students. Lesson plan compiled for each basic competence which can be implemented in one or more meetings. Teachers designing lesson plans for each meeting tailored to scheduling in the education unit.

Here's an explanation regarding Permendikbud the above is; Identity of subjects, including: education unit, class, program/membership program, subject or theme of the lesson, the number of meetings. Standards of competence is a minimum qualification of students who describe the ability of the acquisition of knowledge, attitudes, and skills to be achieved in each class. Basic competence is the ability to master a number of students in certain subjects as a reference to the development of indicators of competence in a subject. Indicators of competence is a behavior that can be measured and/or observed to demonstrate achievement of certain basic competencies that the reference subject assessment. Competence achievement indicator formulated using the verb operations that can be observed and measured,

Components/systematics lesson plan according to the curriculum in 2013 include "(1) the purpose of learning; (2) the learning materials; (3) methods of learning; (4) the learning resources (5) ratings. "systematics manufacture lesson plan refers to Permendikbud No. 81A. Model lesson plan called Tyler a model that has four sequential steps, namely; (1) special purpose; (2) selecting learning activities; (3) organization of learning activities; (4) determine the methods and assessment.

\section{Language Learning}

Said learning more emphasis on teaching learners in earnest involving aspects of intellectual, emotional, and social. According to Brown (2000), learning is the "possession or acquisition of knowledge about the subject or a skill to learn, experience or instruction".

Learning can develop the skills of learners, able to apply his knowledge in the context of everyday life, and learning become an important way to enable learners to experience what they will encounter in everyday life.

\section{English Syllabus}

Syllabus interpreted as a lesson plan on a group of subjects with a particular theme that includes a competence standard, basic competence, learning materials, learning activities, indicators of learning outcomes, assessment, allocation of time and learning resources developed by each educational unit. Syllabus is a translation of the curriculum into the components of teaching and learning at all levels of education programs / training outlined in the curriculum in a coherent, detailed, and operational.

According to Curriculum 2013, the syllabus is a lesson plan on a subject that covers core competencies, basic competencies, learning materials, learning activities, assessment, allocation of time and resources to learn. In accordance with the needs of the educational unit level is concerned.

According to Wilkins in Rajaee, Abbaspour, Javad (2013) that syllabuses are specification of the content of language teaching which have been submitted to some degree of structuring or ordering with the aim of making teaching and learning a more effective process. The syllabus is a specification language teaching content so that the learning process is more effective to achieve the learning objectives. 


\section{Learning objectives of English as a Foreign Language}

According to Cameron (2001) defines learning goals are objectives or intended learning for particular learners working on particular tasks, made specific from the general learning aims of book or syllabus. The purpose of learning is the purpose of having an important role in teaching and learning, as a clear goal to provide a clear direction as well to the selection of learning materials, the selection of appropriate methods, the use of props as appropriate, and the development of evaluation tools are applied. Further, according to Zlatovi, Balaban and Kermek (2015), definition of Learning Goals (i.e. Learning Objectives): “...brief, clear statements that describe the desired learning outcomes of instruction; i.e., the specific knowledge, skills, values, and attitudes students should exhibit that reflect the broader goals. The learning objectives are: short and clear statement on the results of such learning; increased knowledge, skills, values and attitudes of learners. Learning aims to create a continuous change in the behavior and thinking of learners in a learning environment.

\section{Teaching Materials}

Learning materials is the content or materials provided to students during the learning process. According to Nation and Macalister (2010): (1) based on the simple-complex sequences; (2) based on chronology; (3) based on need; (4) based on the prerequisite of learning; (5) based on the sequence of whole-part or parts of a whole; (6) based on a spiral sequence. By using the criteria set by the Mecalister the teaching materials are used in English language learning and the quality will suit the needs of students.

This is in accordance with the opinion Tamas and Szabo (2017) that said, material dimensions of education and learning, bringing together a cluster of emerging scholarly ventures that investigate how people create, explore, interpret, negotiate, adjust, contest, transform and envision learning environments. The material dimension of learning is how to make someone can investigate, interpret, negotiate, modify and customize the learning environment.

In line with these opinions Meraji and Zamanian (2014) also said, considering the obtained results it was concluded that compared to materials containing only the second language culture, the culturally adopted materials were more useful for learners and were able to improve the overall learning of the EFL learners in a more effective way. Teaching materials that adopt the values of the target language culture can improve the language skills of learners. Quality teaching materials are prepared based on the needs of learners and educators, learners' cognitive development, and follow the development of science, information and communication technology.

\section{Assessment}

Based on Permendikbud number 1042014 that Learning Outcomes Assessment by educators is the process of collecting information/evidence about the learning achievements of learners within the competence of spiritual attitudes and social attitudes, competencies, knowledge, skills and competence are done in a planned and systematic, during and after the learning process. (Permendikbud Number 104 of 2014).

Assessment is a process to determine whether the process and the results of a program activity in accordance with the objectives or criteria that have been set. Measurement is always concerned with the quantitative aspects of the form of data while the evaluation is an overall assessment of educational programs including the planning of a substance education program including curriculum, assessment of implementation, procurement, capacity building of teachers, educational management and overall education reform.

In accordance with curriculum guidelines in 2013 specifically to aspects of assessment of learning outcomes, teachers must use authentic assessment and rubric. Authentic assessment has the advantages of a real, genuine, valid and reliable and can reveal the overall attitude, knowledge and skills after the learners learn. While the rubric used by teachers as an instrument to assess the tasks learners who have aspects that have assessed the levels/grading assessment. Things were rated a learner performance tasks and rubrics are stored in the form of portfolio and anecdotal records for certain periods as information regarding traveling and learning process.

\section{Research Methods}


As an evaluative research, the approach used is a qualitative approach to the evaluation method of learning the English language refers to the flow of DEM models developed by Malcolm M. Provus, Evaluation of this model consists of three stages/phases; the application of the principles of the preparation of the implementation of learning, the implementation of measures preparing the implementation of learning, and implementation of lesson plan English. This research was conducted in junior Seraphine Bakti Utama in West Jakarta. For the purposes of this study, the selection of informants is purposive, that is based on the intent of the study. Criteria for selecting informants, among others: (1) The principal, (2) Teacher; (3) Students. The data collected in this study conducted through structured interviews, in-depth interviews, document searches, and observation.

\section{Results and Discussion}

\section{Application of the Principles of Lesson Plan English}

Based on the research findings can be explained that the teachers in preparing lesson plans as a whole does not contain a basic competence spiritual attitudes, social attitudes, knowledge, and skill, but of teachers in preparing lesson plans can be implemented in one or more than one meeting with a value of $10 \%$. Teachers pay attention to individual differences of students in preparing the lesson plan with a value of $10 \%$. However lesson plan compiled no more student-centered teacher-centered. Teachers also develop independent learning with a value of $10 \%$ for giving homework to students. Teachers do not provide feedback and follow-up and provide direct learning new teaching materials.

Lesson plan compiled have relevance and coherence competence and utilize information and communication technologies in preparing the lesson plan.

The learning process is designed to encourage student-centered motivation, interest, creativity, initiative, inspiration, independence and willingness to learn to use the scientific approach include observing, ask, gather information, reason / associate and communicate. Meanwhile, according to Scrimin (2018) that; it means that self-regulated students are internally driven and supported by motivation in setting their learning goals, implementing effective learning strategies, monitoring their progress, establishing environmental conditions conducive to learning, and keeping a sense of self-efficacy for learning.

Learners can learn independently, self motivated if supported by the learning objectives, implementing strategies for effective learning, monitoring the progress of learners, applying a conducive environment for learners. A learning process cannot be separated from teaching and learning.

The learning process that makes the surrounding environment as a learning resource. The learning environment is all that can be heard and seen that also affect language communication process. For more details, which included the language environment is like the situation in the classroom during the learning process takes place, in markets, shopping malls, restaurants, a conversation group of people, while watching television, when reading media or various other reading materials as well as the situations in other environments. So the language environment is not limited to the conditions, time and the environment. It is appropriate according to Jakonen (2017) that says; the material environment of a classroom does not only work as a possible resource for action but it can also be the target of participants' action, typically in and through different kinds of textual practices but also in the instruction of various hands-on activities.

Material language environment in the classroom not only serve as an increase in human resources. However, as a target to achieve the learning objectives and to facilitate the growth of language. Therefore, a good language environment is an environment that can provide greater opportunities for learners to acquire new language learned.

The learning process is done interactively between teachers and learners, where both parties actively play a role and act within a framework and mutually agreed frameworks. The linkage activities learners with activities of teachers in learning activities is a link between stimulus and response. According to research results Hwang and Wang (2016) said, therefore, the purpose of situated learning is to develop students' ability of applying the knowledge gained in school in real-world contexts, and so the provision of learning contexts has become an essential way of enabling students to experience what they might encounter in their daily lives.

Learning objectives is to develop the skills of learners, able to apply his knowledge in the context of everyday life, and learning become an important way to enable learners to experience what they will encounter in everyday life. The final goal of the process is the attainment of learning. Learning success can 
be influenced by several factors. According to Dallingeret. al., (2016) that: educational effectiveness research theoretically argues and empirically shows that learning is most strongly influenced by students' characteristics, such as prior achievement, general cognitive abilities, motivation, or demographic factors, followed by classroom factors, i.e., instructional quality or classroom composition.

Based on some research both theoretically and practically said that the success of learning is influenced by the characteristics of learners, learners' achievements, cognitive ability, motivation, or demographics, followed by class factors, namely instructional quality or composition of the class.

Based on the above it can be concluded that the design aspects of the program gain value $40 \%$ which is a measure of the value of below standard so that it can be interpreted that a gap is negative (-) which is at a value quadrant $(-2)$ for the majority of teachers in preparing lesson plans are not using the principles of preparation of the lesson plan in accordance Permendikbud Number 103 of 2014 on Basic Education and Learning In Secondary Education.

\section{Steps Lesson Plan}

Based on the findings described in the preparation of lesson plans that teachers undertake measures such as assessment syllabus with $10 \%$ before preparing a lesson plan, but the teacher did not do formulating achievement indicators at KI KD-1, KI-2, KI-3, and KI-4. Learning materials with a value of $10 \%$ in the preparation of lesson plans, teachers also do the elaboration of learning activities with a value of $10 \%$, the teacher also determines the allocation of time in the RPP with a value of $10 \%$. However, teachers do not develop learning assessment, teachers identify learning strategies with a value of $10 \%$, and teachers identify Media, Equipment, Materials and Learning Resources. With a score of $10 \%$.

In the study syllabus includes: (1) KI and KD; (2) the learning materials; (3) the learning process; (4) assessment of learning; (5) the time allocated; and (6) a source of learning. Formulation of indicators of achievement at KI KD-1, KI-2, KI-3, and KI-4. Learning Materials can be derived from textbooks and teacher guide books, other learning resources such as local content, the materials present, the learning context of the surrounding environment are grouped into material for regular learning, enrichment and remedial. In accordance with the needs of the educational unit level is concerned. According Dvorghets and Shaturnaya (2015) that; A well-designed Module syllabus would also include lectures giving knowledge of media genres, production contexts, and case studies so that students have a set of facts, concepts, and theories that they can draw on as they practice critical interpretation, analysis, evaluation, and explanation. A good syllabus module syllabus that contains the media, genre, context, case studies, practice, analysis, evaluation, and explanations. Syllabus serves as a reference in the preparation of lesson plan, which means that the syllabus as the planning of the learning process is not yet final, it must be followed up with a lesson plan, so the focus and concrete.

Translation of learning activities that exist in the syllabus in the form of a more operational form of scientific approach adapted to the conditions of the students and educational units including the use of media, tools, materials, and learning resources. The allocation of time for each meeting based on the allocation of time on the syllabus, further divided into preliminary activities, the core and the cover.

In line with the above opinion, Lunina and Minaeva (2015) in his research also says that learning materials can be made out of various source videos thus offering a wide range of topic and varieties of english depending on the needs of learners. Learning materials can be made from a variety of video sources that offer a wide range of topics in English depending on the needs of learners. According to Kirk, Mininger and Laird (2016) that; language instruction proved to be effective for comunicating novel tasks, allowing an instructor to describe the fundamental knowledge required to define a task: the available actions, goals, constraints on solutions, hierarchical task structures, and procedures for solving the problem.

Language learning can be effective if educators can describe the learning basic knowledge such as: actions, goals, constraints, solutions, tasks, and procedures for troubleshooting. The purpose of learning the English language also refers to the communicative competence, ie the ability to master knowledge of the language and the ability to use the language properly. Further, according to Zlatovi, Balaban and Kermek (2015) that; definition of Learning Goals (i.e. Learning Objectives): “...brief, clear statements that describe the desired learning outcomes of instruction; i.e., the specific knowledge, skills, values, and attitudes students should exhibit that reflect the broader goals. 
Learning objectives are: short and clear statement on the results of such learning; increased knowledge, skills, values and attitudes of learners. Learning aims to create a continuous change in the behavior and thinking of learners in a learning environment.

In addition there is another definition which states that the method of learning is the way that teachers use to facilitate the announcements about the material in order to achieve the goal. As the results of research Shawer (2017) who said that; they adapt and supplement the of ficial curriculum's learning outcomes. Instead of following coursebooks, they decide on their teaching topics (syllabus), supply and write their material (content), and use their teaching methods and techniques (activities). To complement the learning outcomes in the curriculum. Educators in teaching can specify topics (syllabus), providing and writing teaching materials (content), and using the methods of teaching and learning techniques.

Based on the above it can be concluded that the aspects of the operation of the program gain value $60 \%$ which is a measure of the value above the standard so that it can be interpreted that a gap is positive $(+)$ which is at a value quadrant (2) because the vast majority of teachers in preparing lesson plans using the steps in the preparation of RPP in accordance Permendikbud No. 1032014 on Basic Education and Learning In Secondary Education.

\section{Implementation of Lesson Plan English}

Based on the research findings can be explained that preliminary activities teachers are only implement $10 \%$, core activities only apply $20 \%$ and activity cover only implemented $10 \%$.

Aspects of product program is based on the evaluation criteria referring to the preliminary activities, core activities, and closing activities. Preliminary activities conducted primarily to create early learning atmosphere to encourage students to focus himself in order to be able to follow the learning process well. The nature of the preliminary activities are activities for heating.

In its core activities focused on activities aimed at the development of capabilities. Presentation of learning materials is done by using various strategies / methods vary and can be done in the classical style, small groups, or individuals. The nature of the cover is to summarize the activities of learning.

Furthermore it is said Harmer (2005) that a technique is implementational that which actually takes place in the classroom ...to accomplish an immediate objective. Technique must be consistent with an approach as well. The technique is implementation, ie what actually happens in the classroom is to achieve specific objectives. Techniques must be aligned with the method and hence should not be contrary to the approach. In other words, the technique is a description of the method, while the method is the elaboration of an approach. Examples of the kinds of techniques commonly used in language learning techniques such as roleplaying, debates, discussions, questions and answers, games, and others.

In addition, the method adopted by the teacher more ranges in the classroom, so that the application of methods in the field or outside the classroom is never done as directly invites students to see what kind of plant, type of plant, or associated with the school environment in time for teaching vocabulary learning about the introduction of plant species, plant species, and the school environment. This is important to do so that students can understand the intent of the teacher directly. Further, according to Chik and Ho (2017) argued that language learners are doing more beyond the classroom to complement, enhance or supplement classroom learning. Language learning can be done outside the classroom to supplement classroom teaching weakness.

In the aspect of the closing activities was found that teachers do not make a summary/concluding lesson summaries while important lesson for students to understand the overall teaching materials provided by the teacher through a summary of teaching materials. Moreover, teachers do not reflect on the activities that have been implemented. Even teachers do not provide feedback on the process and learning outcomes; and teachers do not make an assessment of each completed the learning process, not planned follow-up activities in the form of learning remedial, enrichment programs, counseling services and / or assign a task both tasks individually or in groups according to the learning outcomes of students and teachers do not convey the lesson plan at the next meeting.

Based on the above it can be concluded that the aspects of the operation of the program gain value $40 \%$ which is the standard measure of value under so that it can be interpreted that a gap is negative (-) which is at a value quadrant (-2) for the majority of teachers in the implementation did not correspond Permendikbud No. 103 of 2014 on Basic Education and Learning In Secondary Education. 


\section{Conclusion}

In the aspect of the implementation of the principles of learning lesson plan get a value of $40 \%$ which is below the standard measure of value in that it can be interpreted that a gap is negative (-) which is at a value quadrant (-2) because most educators in preparing the lesson plan did not use principles lesson plan drafting principles in accordance Permendikbud No. 103 of 2014 concerning the Learning In Primary and Secondary Education. In particular on full load basic competence spiritual attitudes, social attitudes, knowledge and skills, student-centered, context, contemporary, feedback and integration.

In the aspect of the application of the preparation of the implementation measures of learning lesson plan get the value of $60 \%$ which is a measure of the value above the standard so that it can be interpreted that a gap is positive (+) which is at a value quadrant (2) because most of the teachers in preparing lesson plans using step- RPP preparation step according Permendikbud No. 103 of 2014 concerning the Learning In Primary and Secondary Education. Especially in the aspect of the syllabus assessment, and the development of learning assessment.

In the aspect of the implementation of the lesson plan lesson plan get the value of $40 \%$ which is below the standard measure of value in that it can be interpreted that a gap is negative (-) which is at a value quadrant (-2) for the majority of educators in practice does not conform Permendikbud No. 103 years 2014 on Basic Education And Learning In Secondary Education. Especially in the aspect of preliminary activities, core activities and cover.

\section{Recommendation}

The proposed any recommendations based on the evaluation carried out are;

1. Recommended should plan the implementation of learning English in junior Seraphine Bakti Utama West Jakarta refers Permendikbud No. 103 of 2014 concerning the Learning In Primary Education and Secondary Education and the curriculum in 2013 as it includes the principles of lesson plan including basic competence spiritual attitudes, social attitudes, knowledge and skills, can be implemented in one or more than one meeting, pay attention to the individual differences of learners; learner-centered; based context; contemporary-oriented, develop independent learning; provide feedback and follow-up study, have relevance and coherence competence and utilize information and communication technology.

2. Recommended program should be operational implementation of learning English in junior Seraphine Bakti Utama West Jakarta refers Permendikbud No. 103 of 2014 on Basic Education and Learning In Secondary Education. As it includes the steps preparing lesson plans include assessments syllabus, the formulation of indicators of achievement KD at KI-1, KI-2, KI-3, and KI-4, material Learning, the translation of the learning activity, the determination of the allocation of time, the development of learning assessment, determine the learning strategies and determine media, tools, materials and learning resources.

3. Recommended product should be in the program refers to Permendikbud Number 1042014 About the Assessment of Learning Outcomes by Teachers In Elementary Education and Secondary Education. Because it constitutes a preliminary activity, core activities and closing activity.

\section{Acknowledgments}

Acknowledgments are conveyed to all the academic community of Jakarta State University, Junior high school principal Seraphine Bakti Utama West Jakarta, teachers, students who have facilitated the implementation of research, discussion of the evaluation of RPP English, and all those who helped during the execution of this study from beginning to end.

\section{Reference}

[1] Neumann, Jan, Andrew Robson, Diane Sloan. (2017). Monitoring and Evaluation of Strategic Change Programme Implementation. International Journal Evaluation and Program Planning, 66.

[2] Mamaril, Molly N. Linda J. Cox, Mehana Vaughan. (2017). Weaving evaluation into the Waipa ecosystem: Placing evaluation in an indigenous place-based educational program. Studies in Educational Evaluation, 56.

[3] Cimmings, Thomas G. Christopher G. Worley. (2015). Organization Development \& Change 10 Editions. USA: Cengange Learning. 
[4] Royse, David, Bruce A. Thyer, Deborah K. Padgett. (2010). Program Evaluation: An Introduction, $5^{\text {th }}$ Edition. New York: Cengange Learning.

[5] Provus, Malcolm M. (1969). The Discrepancy Evaluation Model: An Approach to Local Improvement and Development. Pennsylvania: U.S. Departement or Health, Education \& Welfare Office of Education.

[6] Madaus, Scriven dan Daniel L. Stufflebeam. (2002). Evaluation Models View points and Education and Human Service Evaluation. New York: Kluwer Academic Publishers, Boston.

[7] Permendikbud Nomor 103 tahun 2014 tentang Pembelajaran Pada Pendidikan Dasar Dan Pendidikan Menengah Pasl 1 ayat 2.

[8] Brown, H. Douglas. (2000). Principles of Language Learning and Teaching. New York: Pearson Education.

[9] Permen No 59 tahun 2014 tentang Kurikulum 2013.

[10] Nia, Rajaee, Mahdi, Esmaeil Abdolahzadeh. (2013). A Critical Review Of Recent Trends In Second Language Syllabus Design and Curriculum Development. International Journal of Research Studies in Language Learning

[11] Lynne, Cameron. (2001). Teaching Languages to Young Learners. New York: Cambridge University Press.

[12] Zlatovi, Miran, Igor Balaban, Dragutin Kermek. (2015). Using Online Assessments to Stimulate Learning Strategies and Achievement of Learning Goals. International Journal Computers \& Education.

[13] Nation, I.S.P. dan John Macalister. (2010). Language Curriculum Design. New York: Routledge.

[14] Tamas, Petteri Laihonen dan Peter Szabo. (2017). Studying the Visual and Material Dimensions of Education and Learning. International Journal Linguistics and Education.

[15] Meraji, Seyedeh Maryam, Mustafa Zamanian. (2014). Incorporation of L1 Culture into Second Language Materials Development: Benefits vs. Risks. International Journal Procedia - Social and Behavioral Sciences.

[16] Permendikbud Nomor 104 Tahun 2014 Tentang Penilaian Hasil Belajar Oleh Pendidik Pada Pendidikan Dasar Dan Pendidikan Menengah, Pasal 1 ayat 1.

[17] Scrimin, Sara, Elisabetta Patron, Erlis Ruli, Clovis Euloge Kenne Pagui. (2018). Dynamic Psychophysiological Correlates of a Learning From Text Episode in Relation to Reading Goals. International Journal Learning and Instruction.

[18] Jakonen, Teppo. (2017). The environment of a Bilingual Classroom as an Interactional Resource. International Journal Linguistics and Education.

[19] Hwang, Gwo-Jen dan Siang-Yi Wang. (2016). Single Loop or Double Loop Learning: English Vocabulary Learning Performance and Behavior of Students in Situated Computer Games With Different Guiding Strategies", International Journal Computers \& Education, 102.

[20] Dallinger, Sara, Kathrin Jonkmannb, Jan Hollma, Christiane Fiege. (2016). The Effect of Content and Language Integrated Learning on Students' English and History Competences e Killing Two Birds With One Stone?. International Journal Learning and Instruction, 41.

[21] Dvorghets, Olga S. Yelena A. Shaturnaya. (2015). Developing Students' Media Literacy in the English Language Teaching Context. International Journal Procedia-Social and Behavioral Sciences.

[22] Lunina, Mikhail dan Ludmila Minaeva. (2015). Translated Subtitles Language Learning Method: a New Practical Approach to Teaching English. International Journal Procedia-Social and Behavioral Sciences, 199.

[23] Kirk, James, Aaron Mininger, John Laird. (2016). Learning Task Goals Interactively With Visual Demonstrations. International Journal Biologically Inspired Cognitive Architectures.

[24] Shawer, Saad F. (2017). Teacher-Driven Curriculum Development at the Classroom Level: Implications for Curriculum, Pedagogy and Teacher Training”, International Journal Teaching and Teacher Education, 63.

[25] Harmer, Jeremy. (2005). The Practice of English Language Teaching. Great Britain: Longman.

[26] Chik, Alice dan Jenifer Ho. (2017). Learn a Language for Free: Recreational Learning Among Adults. International Journal System. 